\title{
Antioxidant and antibacterial activity of Acorus calamus. $L$ leaf and rhizome extracts ${ }^{1}$
}

Antioksidan dan aktivitas antibakterial ekstrak daun dan rizoma Acorus calamus. $L$

Kho See $\mathrm{Li}^{2}$, Chan Sook Wah ${ }^{2}$

${ }^{2}$ School of Biosciences, Taylor's University, Selangor, Malaysia

\begin{abstract}
Background: Acorus calamus (sweet flag) is a well-known traditional herb used in India. There were only limited studies done on both hydrophilic and hydrophobic extracts of A. calamus and the biological activities of phenolic and flavonoid compounds as well as alphaasarone in sweet flag. Objective: The present study was designed to explore the antioxidant and antibacterial activities of both hydrophilic and hydrophobic of A. calamus leaf and rhizome extracts. Lastly, the correlation between the biological activities and total phenolic content (TPC), total flavonoid content (TFC) as well as total alpha-asarone content (TAC) of three different extracts (water, hexane and methanol extracts) was revelead. Method: TAC was determined through using HPLC method, while TPC and TFC were determined through spectrophotometric method. DPPH-free radical scavenging assay (DPPH-FRS) and ferric reducing power assay (FRAP) were used to analyse antioxidant activity, whereby disc diffusion method was used to analyse the antibacterial activity. Results: Methanol extracts had significantly $(p<0.05)$ highest levels of antioxidant activities, antibacterial activity TPC $\left(4.466 \%^{1} ; 3.603 \%{ }^{2}\right)$ and TFC $\left(12.819 \%{ }^{I}\right.$; $\left.7.411 \%^{2}\right)$ content. The significant $(p<0.05)$ highest TAC was observed in hexane extracts $\left(0.762 \% ; 2.975 \%{ }^{2}\right) . T P C(p<0.05 ; r=0.855)$ and TFC ( $p<0.05 ; r=0.855)$ correlated to FRAP, while DPPH-FRS solely correlated to TFC ( $p<0.05 ; r=0.873)$ Conclusion: Both of the hydrophilic and hydrophobic extracts of A. calamus could be potent antioxidant agents for nutraceutical application and antibacterial agent for food application. Lastly, flavonoids and phenols extracted from sweet flag could be a good potent source of antioxidants for nutraceuticals or food additives as those compounds are correlated to the antioxidant activity.

${ }^{1}$ Leaf extract; ${ }^{2}$ Rhizome extract
\end{abstract}

KEY WORDS: A. calamus; alpha-asarone; antibacterial; antioxidant; flavonoids; nutraceuticals; phenols; sweet flag

\begin{abstract}
ABSTRAK
Latar belakang: Acorus calamus (minyak atsiri) adalah ramuan tradisional terkenal yang digunakan di India. Hanya ada sedikit penelitian yang dilakukan pada kedua ekstrak hidrofilik dan hidrofobik dari A. calamus dan aktivitas biologis senyawa fenolik dan flavonoid serta alpha-asarone pada minyak atsiri. Tujuan: Mengetahui antioksidan dan aktivitas antibakteri hidrofilik dan hidrofobik daun A. calamus dan ekstrak rhizome serta korelasi antara aktivitas biologis dan total phenolic content (TPC), total flavonoid content (TFC) dan kandungan total alpha-asarone (TAC) dari tiga ekstrak yang berbeda (air, heksana, dan ekstrak metanol). Metode: TAC ditentukan dengan menggunakan metode HPLC sedangkan TPC dan TFC ditentukan melalui metode spektrofotometri. DPPH-free radical scavenging assay (DPPH-FRS) dan ferric reducing power assay (FRAP) digunakan untuk menganalisis aktivitas antioksidan serta metode disc diffusion digunakan untuk menganalisis aktivitas antibakteri. Hasil: Ekstrak methanol memiliki aktivitas antioksidan tertinggi secara signifikan $(\mathrm{p}<0,05)$, kandungan aktivitas antibakteri TPC $\left(4,466 \%{ }^{1} ; 3,603 \%^{2}\right)$ dan TFC $\left(12,819 \%{ }^{1} ; 7,411 \%^{2}\right)$. TAC tertinggi secara signifikan terlihat pada ekstrak heksana $\left(0,762 \%^{1} ; 2,975 \%^{2}\right)(\mathrm{p}<0,05)$. TPC $(\mathrm{p}<0,05 ; \mathrm{r}=0,855)$ dan TFC $(\mathrm{p}<0,05 ; \mathrm{r}=0,855)$ berkorelasi dengan FRAP sedangkan DPPH-FRS berhubungan dengan TFC ( $<00,05 ; \mathrm{r}=0,873$ ). Simpulan: Baik hidrofilik maupun hidrofobik dari ekstrak A. calamus dapat menjadi agen antioksidan kuat untuk aplikasi nutraceutical dan agen antibakteri untuk aplikasi makanan. Sementara itu, flavonoid dan fenol yang diekstraksi dari minyak atsiri bisa menjadi sumber potensial baik dari antioksidan untuk nutraceuticals atau pun makanan tambahan sebagai senyawa yang berkorelasi dengan aktivitas antioksidan.

${ }^{1}$ Ekstrak daun; ${ }^{2}$ Ekstrak rimpang
\end{abstract}

KATA KUNCI: A. calamus; alpha-asarone; antibakteri; antioksidan; flavonoid; nutraseutikal; fenol; minyak atsiri

Dipresentasikan pada $7^{\text {th }}$ International Symposium on Wellness, Healthy Lifestyle and Nutrition pada tanggal 3-4 November 2016 di Yogyakarta kerjasama dengan Universiti Sains Malaysia, Malaysia dan Prince of Songkla University, Thailand

Corresponding author: Kho See Li, School of Biosciences, Taylor's University, No. 1, Jalan Taylor's, 47500 Subang Jaya, Selangor, Malaysia, Tel: +603-56295553; Fax:+603-56295001; e-mail: sookwah.chan@taylors.edu.my 


\section{BACKGROUND}

The usage of antibacterial and antioxidant as additives in food are common and necessary during food production due to the global food security and food safety reasons. The undesirable oxidation of lipids or pigments and growth of microorganism in food are always associated with some undesirable changes even causing some harmful issues such as development of food spoilage, food-borne illness and off flavours. All those changes are turning the products to unacceptable or unsafe for human consumption. Hence, the action of adding antioxidants and antibacterial agents from external sources is required in order to increase the shelf-life of products. Butylated derivatives are the most widely use synthetic antioxidants as protective agents in a variety of products. However, they have been restricted from usage due to the potential liver damage and carcinogenic (1). The development of new physiological races of pathogens and increasing resistant strengthen in bacteria resulted existing antibacterial agents are becoming ineffective. Thus, there is an urgent request for developing innovative or alternatives of synthetic antioxidant and antibacterial agents to solve the problems. Owing to the negative perception on synthetic antioxidant or antibacterial food that using botanical antioxidant and antibacterial instead of synthetic become a trend of consumers' choice, even some other plant based extracts had used for commercial purpose on large scale through encapsulation technologies (2). Besides that, the consumption of nutraceuticals (products that contain substances which have physiological properties and purified from food, plant, specific diets, as well as processed foods) is increasing rapidly due to the raising health awareness among public. Nutraceuticals which have antioxidant activity are one of the popular nutraceutical products in the market as they are able to prevent life-threatening diseases such as diabetes, cardiovascular diseases and cancers (3). According to Malaysian Adults Nutrition Survey 2012, fish oil is the most popular food supplement that taken by Malaysian adults due to its antioxidant properties (4). The principle of antioxidant to eliminate the initiation or prevent the progression of life-threatening diseases is based on scavenging the free radicals and other reactive oxygen species such as hydroxyl radical, superoxide anion radical, hydrogen peroxide, oxygen singlet, hypochlorite, nitric oxide radical, and peroxynitrite radical. As those highly reactive free radicals which can cause the homeostatic unbalance as well as oxidative damages to biological macromolecules such as nucleic acid, proteins, carbohydrates, and lipids (5).

In order to solve the aforesaid problems and demands, Acorus calamus or sweet flag could become possible solution as it has reported to possess antioxidant, antimicrobial properties, is a well-known traditional medicinal plant used for numerous diseases treatments in India (6). Thus, this study worked on the extraction of bioactive compounds in terms of antioxidant and antibacterial compounds from $A$. calamus leaf and rhizome involved the use of simple extraction apparatus which is water bath shaker. A. calamus can be found in both temperate and sub temperate zones such as India, China, Indonesia, Japan, Australia, southern Russia, southern Siberia, southern Canada as well as the northern United States. Chemical composition of alcoholic $A$. calamus extract and essential oil had been investigated extensively in nearly 20 years. The findings of previous studies demonstrated that the major chemical constituents of non-aqueous $A$. calamus extract were alpha- and betaasarone. Those bioactive compounds were also found that responsible to most of the biological activities including antioxidant and antibacterial activities. Other than alpha-asarone and beta-asarone, various hydrocarbon compounds also identified in A.calamus. Phenols and flavonoids are group as type of hydrocarbon due to presence of hydroxyl group attached to the hydrocarbon ring on their chemical structure (7). Phenolic and flavonoid compounds are also always reported that have correlated with the antibacterial activity and degenerative diseases such as cancer and cardiovascular diseases $(8,9)$.

However, there were limited studies devoted on the aqueous extract of A. calamus, thus a comparative study of hydrophobic and hydrophilic extracts of sweet flag was conducted to evaluate their antioxidant and antibacterial activities. Besides that, most of the previous studies focused on the biological activity of beta-asarone as well as alpha-asarone, the biological properties of phenols and flavonoids have not been studied extensively. Despite phenolic and flavonoids are not the major compound 
found in sweet flag, numerous of studies of phenolic and flavonoids isolated from fruit and vegetables have been reported to have physiological benefits and sell in the market as nutraceutical products (10). Hence, there is a potential to study the biological activity of phenols and flavonoid from sweet flag. The co-relationship between pharmacological activities (antibacterial and antioxidant) and phenols as well as flavonoids of sweet flag was evaluated through the present study.

\section{METHODS}

\section{Plant material}

A. calamus plants were provided by PS Green (KL, Malaysia). The leaves and rhizomes were removed from the plant and washed thoroughly with tap water. A known amount of leaves and rhizomes were dried in an oven at $40^{\circ} \mathrm{C}$ for 24 hours. After drying, the dried leaves and rhizomes were pulverized in a grinder.

\section{Bacteria strains}

All the bacteria used in the present study were obtained from the School of Bioscience, Taylor's University Subang Jaya, Malaysia. All of the selected bacteria are commonly found in food including Bacillus cereus 10876 (Gram positive), Escherichia coli 25922 (Gram negative), Salmonella. styphimurium 13311 (Gram negative) and Staphylococcus. aureus 29213 (gram positive).

\section{Reagents and materials}

All the reagents and materials used for analyses were tabulated in Table $\mathbf{1 .}$

\section{A. calamus leaf and rhizome pulverization}

The leaves and rhizomes were removed from the plant and washed thoroughly with tap water. A known amount of leaves and rhizomes were dried in an oven at $40{ }^{\circ} \mathrm{C}$ for 24 hours. After drying, the dried leaves and rhizomes were pulverized in a household grinder and the final weight was recorded. The powder of leaf and rhizome was stored separately in Scott bottle at room temperature for further usage.

\section{Extraction and sample preparation}

Dried leaf and rhizome powders were dissolved separately in distilled water, methanol and hexane with a ratio $1: 20(\mathrm{~g} / \mathrm{ml})$. The extraction was performed at $60^{\circ} \mathrm{C}$ on a horizontal water bath shaker (EQ-HS-1176 Memmert, Malaysia) with a middle shaking speed condition for 3 hrs. After 3 hours, Whatman No.1 filter papers were used to filter extracts. The solvent was evaporated from the filtrate through a rotary evaporator (Fischer Scientific EYELA, Malaysia) at $40{ }^{\circ} \mathrm{C}$ for 10 to $30 \mathrm{mins}$. For preparing a $200 \mathrm{mg} / \mathrm{ml}$ of extract stock solution, a known amount of dried extract was dissolved in DMSO. The mixture was treated with ultra-sonication (Elmasonic S 60H Elma Schmidbauer GmbH, Germany) for 10-15 mins in order to hasten and ensure the full dissolution. Then, membrane filter $(0.22 \mu \mathrm{m})$ was used to remove the undissolved residues.

\section{Total alpha-asarone content analysis}

Total alpha-asarone content of leaf and rhizome extracts was quantified by HPLC (Shimazu Prominence UFLC, Japan) equipped with PDA detector (SPD-M30A Shimadzu, Japan) and C18 column. The injection volume was set as $10 \mu \mathrm{l}$ of $50 \mathrm{mg} / \mathrm{ml}$ of DMSO of extract and a mixture of methanol and distilled water $(1: 1, \mathrm{v} / \mathrm{v})$ was used as mobile phase to elute the sample from the column at $35{ }^{\circ} \mathrm{C}$ (CTO-AS vp Shimadzu, Japan) with a $1.0 \mathrm{ml} / \mathrm{min}$ flow rate. The detection of alpha-asarone was carried out at $259 \mathrm{~nm}$ at room temperature $(11,12)$. The standard stock solution was prepared by dissolving $10 \mathrm{mg}$ of alpha-asarone in $10 \mathrm{ml}$ of DMSO. A series dilution was performed in order to obtain seven different concentrations of working solution from $0.1 \mu \mathrm{g} / \mathrm{ml}$ to $250 \mu \mathrm{g} / \mathrm{ml}$.

\section{Total phenolic content analysis}

Folin-ciocalteu method was used to determine the total phenolic content of dried leaf and rhizome extracts (13). An amount of $0.1 \mathrm{ml}$ of extract ( $10 \mathrm{mg} / \mathrm{ml}$ of DMSO) and $5 \mathrm{ml}$ of diluted folin-ciocalteu were added into a tube. After 3 minutes, $4 \mathrm{ml}$ of $1 \mathrm{M}$ of sodium carbonate was added. The assay solution was incubated for 2 hours and measured its absorbance at $765 \mathrm{~nm}$ against a blank 
Table 1. Reagents and materials used for chemical analyses

\begin{tabular}{|c|c|c|c|}
\hline Chemical analysis & Chemical name & Purity & Grade \\
\hline \multirow{5}{*}{$\begin{array}{l}\text { Extraction and } \\
\text { sample preparation }\end{array}$} & Methanol & $\geq 96 \%$ & Analytical \\
\hline & Hexane & & Analytical \\
\hline & Distilled water & & \\
\hline & Whatman No.1 filter paper & & \\
\hline & Dimethyl Sulfoxide(DMSO) & $99.9 \%$ & Analyitcal \\
\hline \multirow[t]{4}{*}{ Quantitative of alpha-asarone by HPLC } & Methanol & $99.8 \%$ & $\mathrm{LC}$ \\
\hline & Distilled water & & \\
\hline & Filter paper & & \\
\hline & $\mathrm{C}-18$ & & \\
\hline \multirow[t]{5}{*}{ Total phenolic content (TPC) } & Gallic acid & $97.5-102.5$ & \\
\hline & Anhydrous sodium carbonate & 99.9 & \\
\hline & Methanol & $\geq 96 \%$ & Analytical \\
\hline & Folin-Ciocalteu's reagent & & \\
\hline & Distilled water & & \\
\hline \multirow[t]{5}{*}{ Total flavonoid content (TFC) } & Catechin & $\geq 98 \%$ & HPLC \\
\hline & Aluminium chloride-6-hydrate & $97.0 \%$ & \\
\hline & Sodium nitrite & & \\
\hline & 1M sodium hydroxide & & \\
\hline & Distilled water & & \\
\hline \multirow{3}{*}{$\begin{array}{l}\text { 2,2-diphenyl-1-picrylhydrazyl (DPPH) } \\
\text { scavenging activity }\end{array}$} & Trolox & $98.1 \%$ & HPLC \\
\hline & Methanol & $\geq 96 \%$ & Analytical \\
\hline & 2,2-diphenyl-1-picrylhydrazyl & & \\
\hline \multirow[t]{7}{*}{ Ferric reducing antioxidant Power (FRAP) } & Gallic acid & $97.5-102.5 \%$ & \\
\hline & Methanol & $\geq 96 \%$ & Analytical \\
\hline & Potassium hexacyanoferrate & $99.0 \%$ & Analytical \\
\hline & Disodium-hydrogen phosphate monohydrate & $99.0 \%$ & Analytical \\
\hline & Sodium-dihydrogen phospahate & $99.0-102 \%$ & Analytical \\
\hline & Trichloroacetic acid & $99.0 \%$ & \\
\hline & Ferric chloride & $99.0 \%$ & \\
\hline \multirow[t]{5}{*}{ Antibacterial activity } & Streptomycin & & $\begin{array}{l}\text { Analytical } \\
\text { standard }\end{array}$ \\
\hline & DMSO & & \\
\hline & Mueller-Hinton agar & & \\
\hline & Mueller-Hinton broth & & \\
\hline & Whatman No.1 filter paper & & \\
\hline
\end{tabular}

with DMSO by a using spectrometer (Lambda XLS spectrometer PerkinElmer, UK). The folin-ciocalteu solution $(10 \% \mathrm{v} / \mathrm{v})$ was prepared by transferred a $10 \mathrm{ml}$ of folin-ciocalteu reagent into a $100 \mathrm{ml}$ volumetric flask and diluted it with distilled water. $1 \mathrm{M}$ of sodium carbonate was prepared by dissolving $10.5989 \mathrm{~g}$ of sodium carbonate in $100 \mathrm{ml}$ of distilled water. A calibration curve was plotted by a series concentration of gallic acid from $200 \mu \mathrm{g} / \mathrm{ml}$ to $1000 \mu \mathrm{g} / \mathrm{ml}$. The $1000 \mu \mathrm{g} / \mathrm{ml}$ of gallic acid stock solution was prepared by dissolving $25 \mathrm{mg}$ of gallic acid in $25 \mathrm{ml}$ of methanol. The total phenolic contents of extracts were expressed as gallic acid equivalent (GAE) in grams per $100 \mathrm{~g}$ of dried extract or percentage.

\section{Total flavonoid content analysis}

Quantitative analysis of flavonoid contents of dried leaf and rhizome extracts was determined by using method with slight modification (14). A volume of 0.5 $\mathrm{ml}$ of sample with known concentration $(10 \mathrm{mg} / \mathrm{ml}$ of DMSO) was mixed with $2.5 \mathrm{ml}$ of distilled water and $0.15 \mathrm{ml}$ of $5 \%(\mathrm{w} / \mathrm{v})$ sodium nitrite. After 6 minutes, 0.3 $\mathrm{ml}$ of $10 \%(\mathrm{w} / \mathrm{v})$ aluminum chloride-6-hydrate and let 
the solution stand for 5 mins follow by adding $1.0 \mathrm{ml}$ of $1 \mathrm{M}$ sodium hydroxide and $0.5 \mathrm{ml}$ of distilled water. The absorbance of the assay was measured at $510 \mathrm{~nm}$ against blank with DMSO by using spectrometer (Lambda XLS spectrometer PerkinElmer, UK). The preparation of 5\% $(\mathrm{w} / \mathrm{v})$ sodium nitrite and $10 \%(\mathrm{w} / \mathrm{v})$ aluminum chloride6-hydrate solution were done by dissolving separately of $5 \mathrm{~g}$ sodium nitrite and $10 \mathrm{~g}$ aluminum chloride-6-hydrate in $100 \mathrm{ml}$ of distilled water. Catechin with $1000 \mu \mathrm{g} / \mathrm{ml}$ concentration was used as the standard stock solution by dissolving $25 \mathrm{mg}$ of catechin in $25 \mathrm{ml}$ of distilled water. The calibration curves were plotted with series concentration of gallic acid solution from $2 \mu \mathrm{g} / \mathrm{ml}$ to $400 \mu \mathrm{g} / \mathrm{ml}$.

\section{2,2-diphenyl-1-picrylhydrazyl (DPPH) scavenging activity}

DPPH radical scavenging activities of dried leaf and rhizome extracts were determined by referring the Devi et al. (2011) method (15). A known concentration of $0.1 \mathrm{ml}$ of sample $(10 \mathrm{mg} / \mathrm{ml}$ of DMSO) was mixed with $2 \mathrm{mM}$ of DPPH solution. The absorbance of assay was measured at $517 \mathrm{~nm}$ after 30 minutes dark incubation by using spectrometer (Lambda XLS spectrometer PerkinElmer, UK). The control tube absorbance was determined by replacing $0.1 \mathrm{ml}$ of sample with $0.1 \mathrm{ml}$ of DMSO. For 2mM DPPH solution preparation was done by dissolving $0.0501 \mathrm{~g}$ of DPPH in $100 \mathrm{ml}$ of methanol. For calibration curve was plotted with various concentration working solution from $0.2 \mathrm{mM}$ to $1 \mathrm{mM}$. The stock solution was prepared by dissolving $0.0501 \mathrm{~g}$ of trolox in $100 \mathrm{ml}$ of methanol. DPPH radical scavenging ability of each sample assay was calculated based on the formula following:

Scavenging $(\%)=1-\frac{\text { Abs of sample assay }}{\text { Abs of control assay }} \times 100 \%$

Where, $\mathrm{Abs}=\mathrm{Abs}$ orbance

\section{Ferric reducing antioxidant power analysis}

Oyaizu method was used to determine the reducing power of $A$. calamus leaf and rhizome extracts with slightly modification (16). The reaction mixture was prepared by mixing $0.1 \mathrm{ml}$ of plant extracts with $10 \mathrm{mg} / \mathrm{ml}$ of DMSO concentration with $2.5 \mathrm{ml}$ of $0.2 \mathrm{M}$ phosphate buffer and $2.5 \mathrm{ml}$ of $1 \%$ of potassium hexacyanoferrate. Then, the reaction mixture was kept onto water bath (EQ-HS-1176, Memmert, Malayisa) at $50{ }^{\circ} \mathrm{C}$ for 20 mins After $20 \mathrm{mins}$ incubation, $2.5 \mathrm{ml}$ of $10 \% \mathrm{TCA}(\mathrm{w} / \mathrm{v})$ was added and filtered through syringe filter $(0.45 \mathrm{um})$ in order to obtain a clear solution. The filtrate was further diluted with $2.5 \mathrm{ml}$ of distilled water and followed by adding $0.5 \mathrm{ml}$ of $0.05 \%$ of ferric chloride. The absorbance was measured at $700 \mathrm{~nm}$ against DMSO as blank by spectrometer (Lambda XLS spectrometer PerkinElmer, UK). The preparation of $0.2 \mathrm{M}$ of phosphate buffer (pH6.6) was done by mixing approximately 77 $\mathrm{ml}$ of $0.2 \mathrm{M}$ disodium hydrogen phosphate with $23 \mathrm{ml}$ of $0.2 \mathrm{M}$ sodium-hydrogen phosphate. An amount of $2.8392 \mathrm{~g}$ disodium hydrogen phosphate and $2.7598 \mathrm{~g}$ of sodium dihydrogen phosphate were dissolved separately in $100 \mathrm{ml}$ of distilled water. In order to prepare $1 \%$ of potassium hexacyanoferraten(w/v), 10\% TCA (w/v) and $0.05 \%$ of ferric chloride $(\mathrm{w} / \mathrm{v})$ solutions, $1 \mathrm{~g}$ of potassium hexacyanoferrate, $10 \mathrm{~g}$ of TCA and $0.05 \mathrm{~g}$ of ferric chloride were used to dissolved in $100 \mathrm{ml}$ of distilled water respectively. Gallic acid was used as standard and prepared in different concentration from $\mu \mathrm{g} / \mathrm{ml}$ to $\mu \mathrm{g} / \mathrm{ml}$.

\section{Antibacterial activity analysis}

Disc diffusion method was used to investigate the antibacterial activity of plant extracts through measuring the diameter of formed inhibition zone. A sterile cotton was dipped into cultures broth of bacteria which had approximately 0.2 optical density at $600 \mathrm{~nm}$ (17). The sterile cotton was streaked through the surface of sterile Muller Hinston agar plate in order to obtain an even inoculum. After that, a blank loaded with $10 \mathrm{ul}$ of 200 $\mathrm{mg} / \mathrm{ml}$ of DMSO extract was placed on the agar surface. Simultaneously, blank disc loaded with $10 \mathrm{ul}$ of $1 \mathrm{ug} / \mathrm{ml}$ of Streptomycin and $10 \mathrm{ul}$ of DMSO were also placed on agar surface act as positive control and negative control respectively. The agar plate was kept into an incubator at $37^{\circ} \mathrm{C}$ for $24 \mathrm{hrs}$ and recorded the diameter of formed inhibition zone. 


\section{Statistical analysis}

All of the results were reported in mean and standard deviation of triplicate determinations. Independent t-test and Mann-Whitney test were used to determine the significant level between leaf and rhizome extracts obtained using same extracting solvent. While One-way analysis of variance (ANOVA) or Kruskal Wallis test were used for determination of significant level among different solvent extracts of leaf or rhizome. Tukey post hoc test or Tammany were used for further analysis of samples with significant difference at $p<0.05$. Pearson analysis or Spearman analysis was performed to evaluate the relationship between biological activities and phytochemicals.

\section{RESULTS}

\section{Total-alpha-asarone content}

Alpha-asarone contents were varied in crude leaf and rhizome extracts obtained from different solvent which fall within $0.01 \%-3 \%$ (Table 2 ). All the rhizome extracts except for water rhizome extract, showed a significant higher $(\mathrm{p}<0.05)$ TAC compared to leaf extracts. Among all the solvents, hexane extracts displayed significant highest TAC among all of extracts obtained from different solvents.
The different small case letters indicate significant difference $(p<0.05)$ in same row. The different digital numbers indicate significant difference $(p<0.05)$ in same column. Values are reported as mean \pm standard deviation of two individual determinations and each determination was performed in triplicate.

\section{Total phenolic content}

Total phenolic content of crude leaf and rhizome extracts obtained from different solvents are presented in Figure 1. Methanol leaf extract displayed the significant highest TPC, however, there was no significant different $(p>0.05)$ in terms of TPC in methanol leaf extract and rhizome extract. The significant difference was only found in leaf and rhizome extracts which obtained from water as well as hexane solvents. In leaf extracts, methanol leaf extract showed the significant highest of total phenolic contents followed by water leaf extract and hexane leaf

Table 2. Alpha-asarone contents in different solvents crude extracts of A.calamus

\begin{tabular}{llc}
\hline & \multicolumn{2}{c}{ Mean $^{\mathrm{n}} \pm$ SD } \\
& \multicolumn{2}{c}{ Alpha-asarone content\% } \\
\cline { 2 - 3 } & \multicolumn{1}{c}{ Leaf } & \multicolumn{1}{c}{ Rhizome } \\
\hline Methanol & $0.27 \pm 0.04^{\mathrm{a} 1}$ & $0.46 \pm 0.04^{\mathrm{b} 1}$ \\
Hexane & $0.762 \pm 0.126^{\mathrm{a} 2}$ & $2.98 \pm 0.11^{\mathrm{b} 2}$ \\
Water & $0.01 \pm 0.00^{\mathrm{a} 3}$ & $0.01 \pm 0.00^{\mathrm{a} 3}$ \\
\hline
\end{tabular}

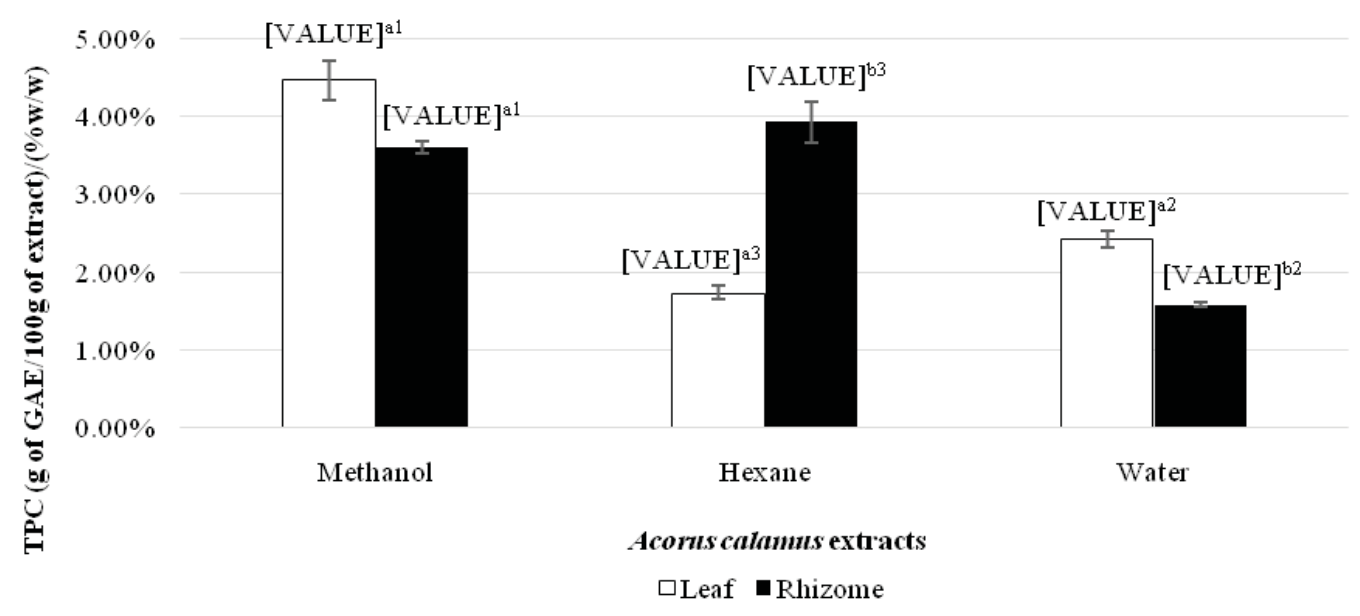

Figure 1. Total phenolic contents of Acorus Calamus leaf and rhizome extracts using 3 different solvents expressed in terms of gallic acid equivalent (g of GAE/100g of extract)/ (w/w\%) 
extract. While for the rhizome extracts, hexane extracts showed the significant highest $(\mathrm{p}<0.05)$ of total phenolic contents followed by methanol and water extracts.

The different small case letters indicate significant difference $(\mathrm{p}<0.05)$ between leaf and rhizome of same extracting solvent. The different digital number indicates significant difference $(p<0.05)$ among solvents used to extract same plant part. Values are reported as mean \pm standard deviation of three individual determinations and each determination was performed in triplicate.

\section{Total flavonoid content}

According to Figure 2, the total flavonoid contents of $A$.calamus extracts varied by the used of solvents and plant parts for extraction. All of the leaf extracts extracted individually from different solvents were identified to contain significant higher amount of flavonoids compared to rhizome extracts $(\mathrm{p}<0.05)$. Methanol solvent was found as the most significant effective $(p<0.05)$ to extract flavonoid in both leaf and rhizome followed by water then hexane. It was observed that effect of solvents on TFC is similar to that on TPC in leaf extracts. The highest TFC was methanol extract followed by water extracts and hexane extract.

The different small case letters indicate significant difference $(p<0.05)$ between leaf and rhizome of same extracting solvent. The different digital number indicate significant difference $(p<0.05)$ among solvents used to extract same plant part. Values are reported as mean \pm standard deviation of three individual determinations and each determination was performed in triplicate.

\section{DPPH-free radical scavenging activity}

The antioxidant activity of A.calamus could be measured by determine the ability to scavenge free radical. Extract which that display a strong scavenging ability indicated it is a great antioxidant agent. As displayed in Figure 3, all the extracts showed different strength of DPPH radical-scavenging. Methanol extract leaf and rhizome extracts showed significant highest level of DPPH scavenging activity. The order of DPPH radical-scavenging activity of the extracts was found to be as follows: methanol rhizome extract, methanol leaf extract, water leaf extract, water rhizome extract, hexane rhizome extract and hexane leaf extract. The ability of DPPH scavenging was found no significant difference $(p>0.05)$ between the leaf and rhizome extracts which obtained from same methanol as well as hexane. However, there was significant difference $(p<0.05)$ in DPPH radical scavenging ability when using different solvents to extract same part of sweet flag, crude extracts obtained from methanol solvent were displayed the

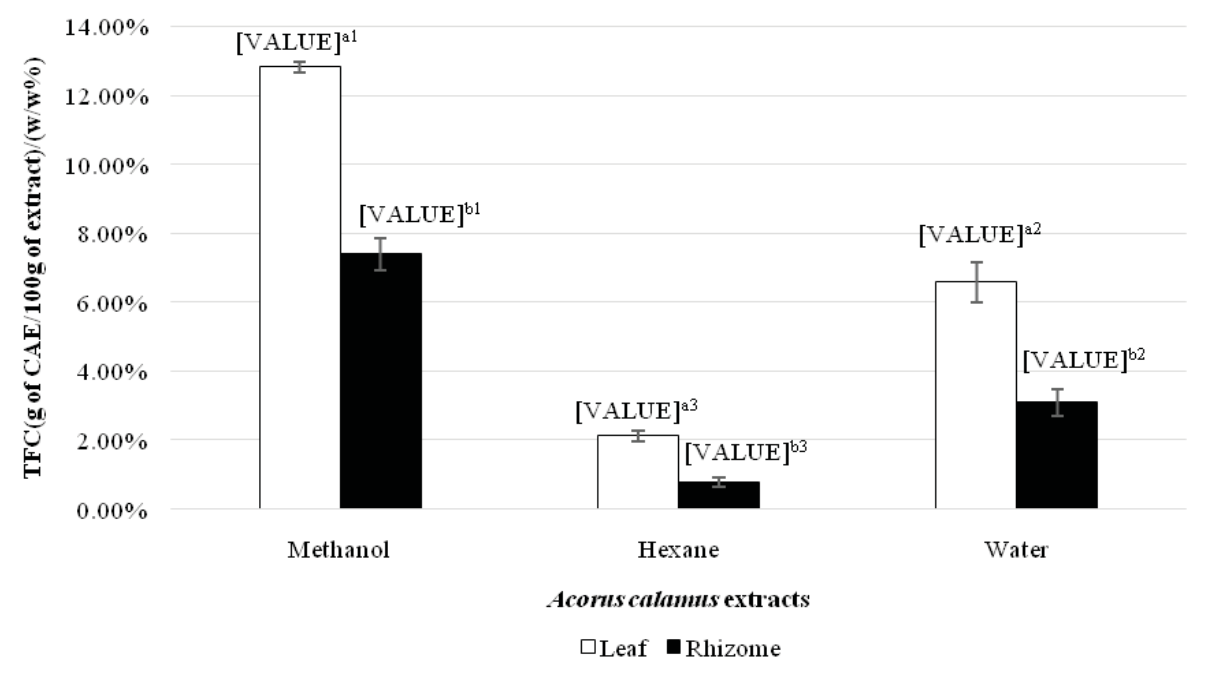

Figure 2. Total flavonoid contents of Acorus Calamus leaf and rhizome extracts using 3 different solvents expressed in terms of catechin equivalent (g of CAE/100g of extract)/(w/w\%) 


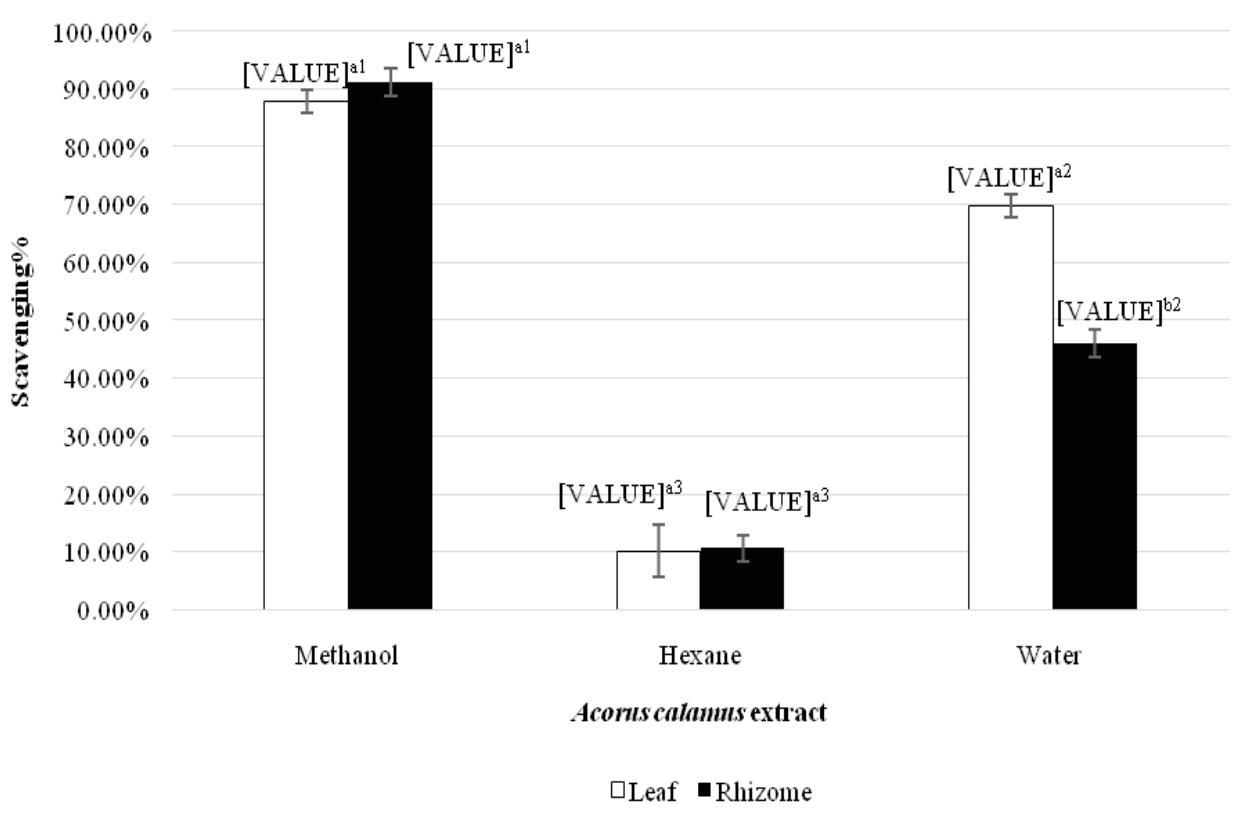

Figure 3. Scavenging percentage of Acorus Calamus leaf and rhizome extracts using 3 different solvents

significantly highest DPPH radical scavenging activity among other solvent.

The different small case letters indicate significant difference $(p<0.05)$ between leaf and rhizome of same extracting solvent. The different digital number indicate significant difference $(\mathrm{p}<0.05)$ among solvents used to extract same plant part. Values are reported as mean \pm standard deviation of three individual determinations and each determination was performed in triplicate.

\section{Ferric reducing antioxidant power}

The antioxidant activity of $A$. calamus could be measured by determine the ability to reduce $\mathrm{Fe}$ (III) to $\mathrm{Fe}(\mathrm{II})$, as the higher the reducing power indicated the higher the antioxidant activity. All of the extracts shown some degree of reducing ability which presented in Figure 4. The reducing power was various in solvent system. In hexane solvent system, rhizome extracts had significant stronger $(\mathrm{p}<0.05)$ reducing powder than leaf extracts, whereas in water system was vice versa. In methanol system, there was no significant different $(p>0.05)$ in term of reducing power. Overall, methanol leaf and methanol rhizome extracts exhibited with highest reducing power follow by either hexane extracts or water extracts. FRAP was found that correlated to the both TPC and TFC. In addition, TFC $(r=0.855)$ had a stronger corelationship than TPC $(r=0.555)$ as a greater co-relation coefficient was obtained, but TAC was not correlated to the reducing power.

The different small case letters indicate significant difference $(p<0.05)$ between leaf and rhizome of same extracting solvent.The different digital number indicate significant difference $(p<0.05)$ among solvents used to extract same plant part. Values are reported as mean \pm standard deviation of three individual determinations and each determination was performed in triplicate.

\section{Antibacterial activity analysis}

In order to evaluate the antibacterial activity of A. calamus, inhibit zone was measured to determine the ability of each extract to inhibit the growth of selected bacteria. The higher the inhibit zone indicated a higher antibacterial activity. The inhibit zone was determined through disc diffusion method and the results are presented in Table 3. All the extracts exhibited comparable antibacterial activity, except for water extracts 


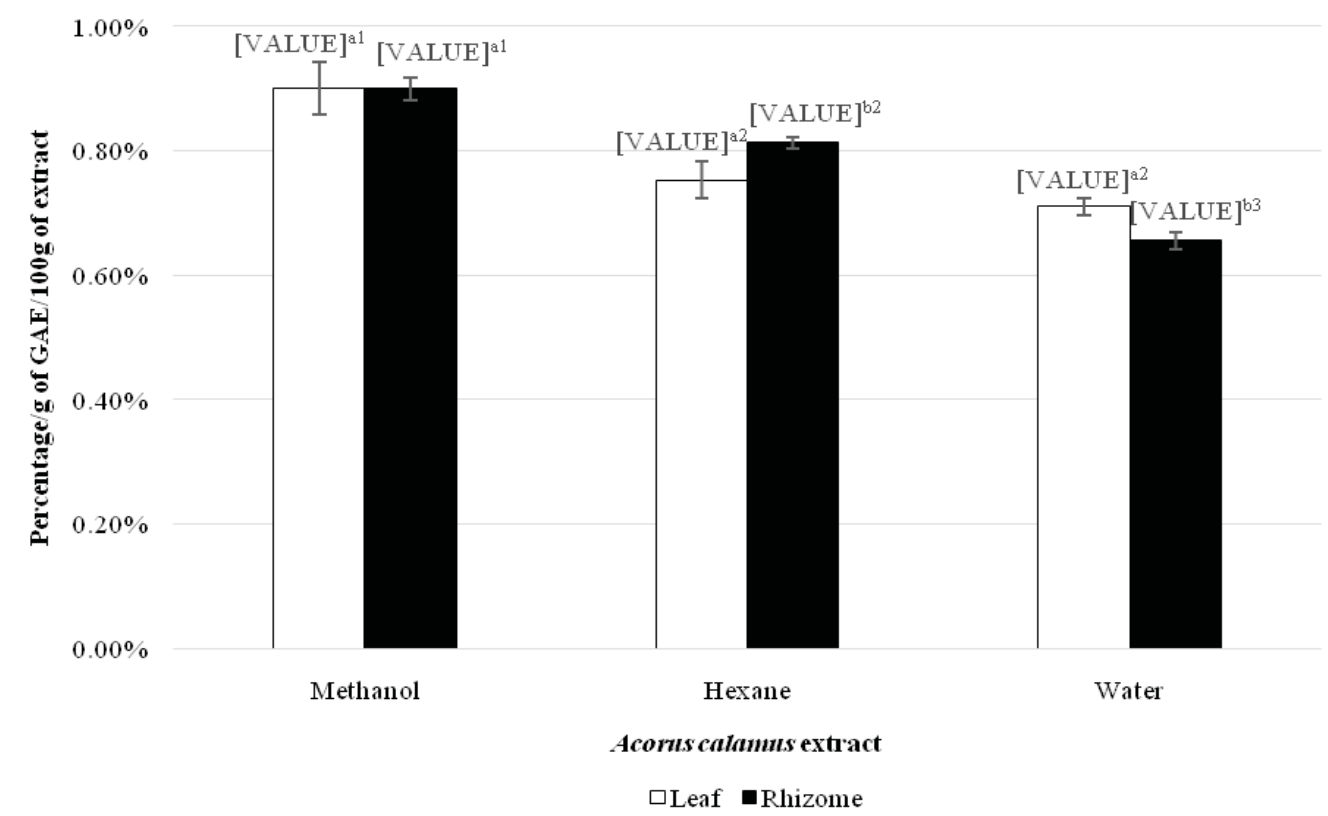

Figure 4. Reducing power of Acorus Calamus leaf and rhizome extracts expressed in terms of gallic acid equivalent (g of GAE/100g of extract)

Table 3. Antibacterial activity in different solvents crude leaf and rhizome extract of A. calamus

\begin{tabular}{lccccccc}
\hline & \multicolumn{9}{c}{ Inhibition zone(cm) } \\
\cline { 2 - 8 } & Strep. & MLE & MRE & HLE & HRE & WLE & WRE \\
\hline B. cereus & $1.18 \pm 0.15$ & $0.85 \pm 0.10$ & $0.9 \pm 0.63$ & $0.84 \pm 0.19$ & $0.85 \pm 0.17$ & $\mathrm{R}$ & $\mathrm{R}$ \\
E. coli & $1.77 \pm 0.23$ & $0.88 \pm 0.10$ & $0.85 \pm 0.06$ & $0.90 \pm 0.07$ & $0.72 \pm 0.05$ & $\mathrm{R}$ & $\mathrm{R}$ \\
S. aureus & $1.88 \pm 0.11$ & $1.20 \pm 0.15$ & $1.20 \pm 0.23$ & $0.78 \pm 0.05$ & $1.20 \pm 0.29$ & $\mathrm{R}$ & $\mathrm{R}$ \\
S. typhi & $1.33 \pm 0.21$ & $0.78 \pm 0.26$ & $1.00 \pm 0.00$ & $0.70 \pm 0.12$ & $0.77 \pm 0.06$ & $\mathrm{R}$ & $\mathrm{R}$ \\
Total & $1.57 \pm 0.35^{\mathrm{a}}$ & $0.93 \pm 0.24^{\mathrm{b}}$ & $0.99 \pm 0.18^{\mathrm{b}}$ & $0.80 \pm 0.13^{\mathrm{b}}$ & $0.89 \pm 0.26^{\mathrm{b}}$ & - & - \\
\hline
\end{tabular}

as no antibacterial activity was observed. Methanol and hexane extracts were demonstrated similar $(\mathrm{p}>0.05)$ and substantial antibacterial activity, although both of their antibacterial activities were weaker than the positive control (Streptomycin). In addition, the antibacterial activity was slightly higher in rhizome extracts compared to leaf extracts when using hexane as the extracting solvent, but the difference was not statistically significant. In contrast, the antibacterial activity was slightly higher in leaf extracts compared to rhizome extracts when using methanol as the extracting solvent, but the difference was not statistically significant TPC and TFC showed weakly positive correlation to antibacterial activity $(p>0.05$; $\mathrm{r}=0.175 ; \mathrm{p}>0.05 ; \mathrm{r}=0.237)$. However, the antibacterial activity of $A$. calamus extracts did not associate with TPC, TFC and TAC, because of the association was not significantly strong $(\mathrm{p}>0.05)$.

The different small case letters indicate significant difference $(p<0.05)$ in the same row. Values are reported as mean \pm standard deviation of two individual determinations and each determination was performed in triplicate. ${ }^{*} \mathrm{R}=$ resistant; Strep. $=$ Streptomycin; $\mathrm{MLE}=$ methanol leaf extract; $\mathrm{MRE}=$ methanol rhizome extracts; HLE = hexane leaf extract; HRE $=$ hexane rhizome extract; $\mathrm{WLE}=$ water leaf extract; $\mathrm{WRE}=$ water rhizome extract 


\section{DISCUSSION}

\section{Total alpha-asarone content analysis}

Alpha-asarone is one of major compound found in A.calamus, according to previous studies, alpha-asarone was also found as the major compound in rhizome oil, which were $9.7 \%$ and $5.5 \%$, respectively (2). However, the literature review of alpha-asarone content in leaf was no available $(18,19)$.

The content of alpha-asarone increased as the polarity of extraction solvent decreased. Significant highest $(p<0.05)$ alpha-asarone contents were identified in hexane leaf and rhizome extracts as the hexane is the solvent that possesses the lowest polarity followed by methanol and water. Low polarity behaviour of alpha-asarone molecule could be the cause of this observation. As the functional groups present in alpha-asarone structure (Figure 5) including ether and methyl are least polar and non-polar, respectively. Polarity of ether functional group is approximate to carbon-carbon bond in alkanes, thus ether and methyl functional groups on alpha-asarone structure show a highly affinity to non-polar solvent hexane instead of polar solvents water and methanol (20). Thus, the higher the polarity of solvent, the lower the amount of alpha-asarone being extracted and vice versa.

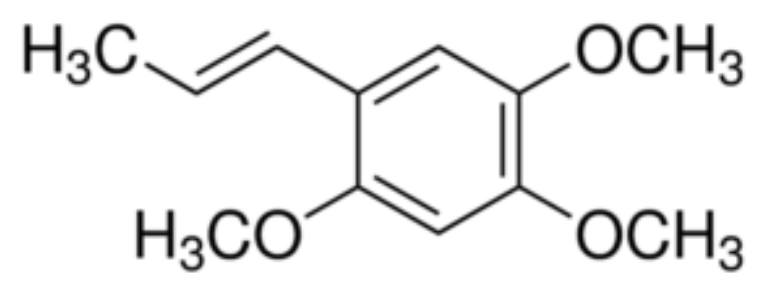

Figure 5. Chemical structure of alpha-asarone (21)

\section{Total phenolic content $\&$ total flavonoid content}

Hexane rhizome extracts were identified with significant highest TPC among all the rhizome extracts, whereas methanol leaf extracts were identified with the significant highest TPC among all the leaf extracts. A similar finding also obtained, non-polar solvents such as chloroform, benzene, and petroleum ether were found to be more effective to extract phenolic compounds in rhizome than polar solvents such as alcohol and water (22).

It might be a possibility that rhizome of $A$. calamus naturally predominates in complex phenolic compounds which are less hydrophilic and leaf predominates in more hydrophobic phenolic compound. Generally, high molecular weight or complex phenolic compounds have long carbon side chains, the hydrophilicity of phenols decreased with the increase in the length of hydrophobic carbon side chain which attached on the benzene ring (23). Hence, rhizome of $A$. calamus naturally predominates in complex phenolic compounds might be the possible reason resulted in hydrophobic solvent hexane existed with higher affinity to phenolic compounds in rhizome than hydrophilic solvent water and methanol

Rhizome displayed a significantly higher total phenolic content when using hydrophobic solvent hexane for the rhizome crude extraction. Whereas, leaf displayed a significantly higher total phenolic when hydrophilic solvent methanol was used as extracting solvent. This observation also could be explained with possibility that rhizome of $A$. calamus naturally predominates in complex phenolic compounds (more hydrophobic phenolic compounds), therefore hydrophobic solvent hexane was more suitable to extract phenolic compound in rhizome while hydrophilic methanol was more suitable to extract phenolic compounds in leaf. Lastly, despite both methanol and water are hydrophilic solvent and able to extract phenolic compound, methanol displayed significantly higher phenolic extracting capability than water. It was because of the most of the phenolic compound are partially dissolved in water (24). As the solubility of phenols in water decreases with increase in side chains which attach on benzene ring, thus the non-polar group becomes predominant and masks the effect of polar $-\mathrm{OH}$ group to form the hydrogen bond with water. Methanol is an amphiphilic solvent which exhibit both polar and non-polar function group, therefore it shown higher TPC extracting capability than water.

Similar to phenolic compounds, the efficiency of flavonoids extraction depends on the polarity. This also might be due to the flavonoids present in A. calamus only partially miscible in water as sweet flag might dominant in high molecular weight of flavonoid with long length of side chain attached on the benzene ring of flavonoid molecule resulted in a low water soluble characteristic. Generally, a mixture of alcohol and water is used to extract flavonoid in plant due to the medium 
polar properties of flavonoids (25). Hence, methanol (hydrophilic) was found as the best solvent to extract flavonoids of sweet flag instead of water (extremely hydrophilic) and hexane (non-polar solvent) was found to be worst solvent. In other hands, the leaf of sweet flag might naturally richer in flavonoids than rhizome, thus the higher TFC was observed in leaf extracts.

\section{DPPH free radical scavenging activity}

Data obtained from TFC analysis which explained various radical scavenging ability conditions. Strong positive correlation $(\mathrm{p}<0.05 ; \mathrm{r}=0.873)$ was found between TFC and scavenging ability. It means that flavonoids might responsible to the free radical scavenging activity of $A$. calamus extracts, the higher the flavonoid content, the stronger the scavenging ability. Despite only TFC strongly associated with DPPH radical scavenging activity, TPC was found weakly correlated $(\mathrm{P}>0.05$; $\mathrm{r}=0.397$ ) to DPPH free radical.

DPPH assay method is a stable and easy method to determine the potential antioxidant activity level in terms of free radicals scavenging of a substance (26). Thus, sweet flag extracts are suggested as the potential source of antioxidant as all the extracts have showed various free radical scavenging ability. The radical scavenging mechanisms of flavonoids have been investigated through previous structure-activity relationship studies of flavonoids. Figure 6 summarizes the structural criteria that modulate the free radical scavenging activity of flavonoids. The studies have pointed out that the presence of 3'4 dihydroxyl catechol structure in the B ring (Figure 6) possessing electron donating properties and being a radical target. The $\mathrm{C} 2-\mathrm{C} 3$ double bond is conjugated with 4-keto group responsible for electron delocalization from the $\mathrm{B}$ ring. Overall, due to the presence of both $3-\mathrm{OH}$ and $5-\mathrm{OH}$ groups in combination with a 4-carbonyl function and $\mathrm{C} 2-\mathrm{C} 3$ double bond, resulting the radical scavenging activity of flavonoids. Hence, flavonoids found in $A$. calamus can be a potent antioxidant as they inhibit the oxidation of radicals by scavenging the radicals through donating electrons to free radicals (27).

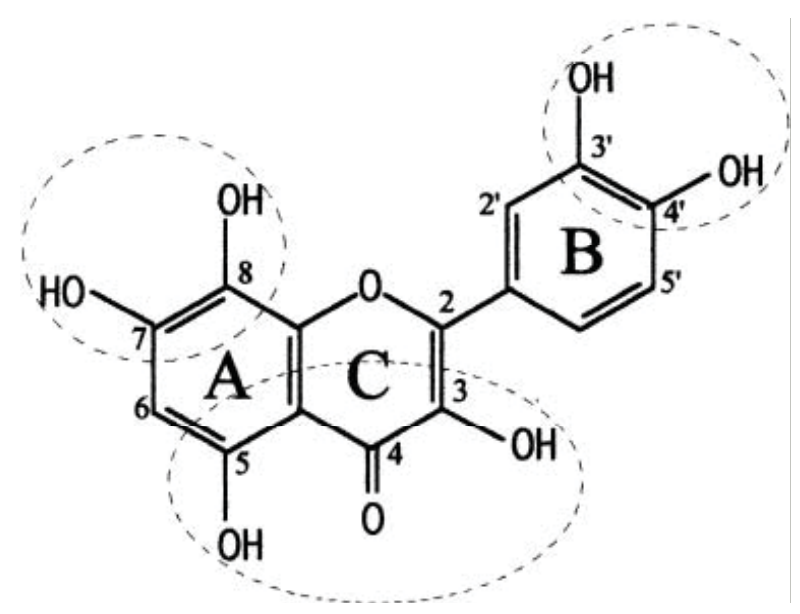

Figure 6. Structure of flavonoids indicating a strong radical scavenging capacity

Similarly, the presence of unsaturated double bond on alpha-asarone structure might be responsible to the radical scavenging properties through electron donation. Study devoted on the antioxidant activity of synthetic alpha-asarone published by Devi et al. (2014), the reduction of DPPH radical in assay caused by an increase of concentration of alpha-asarone (28). This might be due to alpha-asarone and phenols only show their antioxidant properties at a significant concentration. As the amount of alpha-asarone subjected to DPPH assay in the present study [ $30 \mu \mathrm{g}(0.1 \mathrm{ml}$ of $10 \mathrm{mg} / \mathrm{ml}$ of extracts*3\%)] was lower than previous study [200 $\mu \mathrm{g} /$ $\mathrm{ml}(2 \mathrm{ml}$ of $200 \mu \mathrm{g} / \mathrm{ml})]$. Lastly, the inactive principle of alpha-asarone presented in the extracts might associate to this observation.

Another finding regarding the antioxidant activity of methanolic extracts of sweet flag reported by Devi, et al (2011), TFC and TPC also found that exhibited positive correlation with DPPH radicals scavenging activity (15). However, only TFC showed the tight correlation to the DPPH radical scavenging activity in this present study. There are few possible causes to this observation. Firstly, low accuracy of TPC results might be generated due to presence of interferences such as vitamin $\mathrm{C}$, protein, sugars and fiber might affect the absorbance and reduce the consistency of TPC. An overestimated result might occur in TPC analysis as interference of non-phenolic compounds by reacting with the Folin-Ciocalteau reagent such as proteins and sugars $(29,30)$. Those compounds 
are reported to present in A. calamus (Table 4.3) (7), but they do not possess significant free radical scavenging ability. An underestimation result of TPC also might influent the correlation analysis as phenolic compounds of plant always bound to other molecules and unable to react with FC.

\section{Ferric reducing power antioxidant activity}

Since TPC and TFC were associated with reducing activity which suggested that phenols and flavonoids present in A.calamus could be potent bioactive compounds and the source of antioxidant. A similar findings reported that TPC was positively correlated with reducing activity (17). Oppositely, Devi et al (2014) reported that synthetic alpha-asarone is responsible for the reducing power as the reducing power increased with the increase in the concentration of alpha-asarone from $20 \mu \mathrm{g} / \mathrm{ml}$ to $100 \mu \mathrm{g} /$ $\mathrm{ml}$ (28). This suggested that the amount of alpha-asarone successfully extracted by simple water shaker extraction method might be too low to display the antioxidant properties, thus a weak correlation was observed $(\mathrm{r}=0.380 ; \mathrm{p}>0.05)$. The highest concentration of alphaasarone subjected to FRAP analysis in the present study [30 $\mu \mathrm{g}(0.1 \mathrm{ml}$ of $10 \mathrm{mg} / \mathrm{ml}$ of extracts*3\%)] was lower than the highest alpha-asarone concentration subjected to FRAP analysis in Devi et al. (2014) [200 $\mu \mathrm{g}$ ( $2 \mathrm{ml}$ of $200 \mu \mathrm{g} / \mathrm{ml})]$. Therefore, this could be possible reason that explained alpha-asarone was not associated with the antioxidant activity in the present study.

\section{Antibacterial activity}

According to the correlation results, antibacterial activity of A.calamus was not concentration-dependant on TPC, TFC and TAC, hence other bioactive compounds present in the extracts were suspected and contributed to the antibacterial activity. Based on the previous studies, A.calamus extracts were reported that existed antibacterial activity (17). Another similar results published by Joshi et al (2012), both the rhizome essential oil and betaasarone extracted from sweet flag exhibited antibacterial activity against four pathogenic bacteria (31). Therefore, beta-asarone was suspected as another active compound responsible for the antibacterial activity in the present study. Besides that, beta-asarone also displayed relatively stronger antimicrobial activity than alpha-asarone in the study of Joshi et al (2012). This observation supported the explanation of beta-asarone was suspected as the major compound that contribute antibacterial activity of A. calamus extracts instead of alpha-asarone.

Oppositely, an earlier study reported that Salmonella parathypi and Shigella sonnei, Enterococcus faecalis were resistant to both rhizome and leaf extracts $(100 \mathrm{mg} / \mathrm{ml}$ of DMSO) except for Escherichia coli (17). In addition, weak antibacterial activity of $A$. calamus extract also reported by Phongpaichit, et al (2005) (32). While in this present investigation, all the bacteria were treated with a higher concentration of $A$. calamus extracts $(200 \mathrm{mg} / \mathrm{ml}$ of DMSO). Hence, positive antibacterial activity results were observed in this preliminary antibacterial activity analysis. Another important finding reported by Devi, et al (2009), pure form of alpha-asarone and beta-asarone existed significantly greater antimicrobial activity than A. calamus crude extracts (17). Therefore, non-purified A.calamus extracts may also become the possible reason that resulted TAC (alpa-asarone) was not associated with the antibacterial activity in the present study.

Theoretically, the antibacterial activity of $A$. calamus should be strongly correlated with the presence of phenolic and flavonoids. As phenolic acids such as gallic acid and caffeic from other plants have been reported to possess antibacterial activity (33). These compounds were reported present in A. calamus in previous study (34). TPC and TFC exhibited weak relationship $(r<0.250$; $\mathrm{p}>0.05$ ) with antibacterial activity of $A$. calamus extracts in this finding. A low bioavailability and low permeability of phenols and flavonoids extracted from A. calamus could be the possible reason.

Since purification of $A$. calamus extracts was not conducted in the present study, therefore polyphenols in the A. calmus extracts might naturally bound with other compounds such as esters, glycosides and polymers, thus resulting in low permeability against membranes by passive diffusion (35). A low permeability of polyphenols in A. calamus might responsible to the weak association between antibacterial activity and TPC as well as TFC. Besides that, natural form of polyphenols usually requires to undergoes biotransformation in term of changing of 
structure in gastrointestinal cell and liver cell in order to be absorbed and express their pharmacological activity (35). Therefore, bacterial cell also might require to undergo transformation in order to be metabolized by bacterial cells and exert their antibacterial activity in bacterial cells. According to the TPC and TFC results, the concentration of phenolic and flavonoids is relatively low which is approximately less than $10 \%$ except for methanol extracts. A low concentration of bioactive compounds might result in low antibacterial activity. For instance, the phenolic compound will only tend to affect the function of enzyme at low concentration, while they will tend to denature the protein at high concentration (36). Lastly, A.calamus rhizome and leaves extracts must contain active principle of derived compound which is believed to be responsible for their antibacterial activity.

\section{CONCLUSION AND RECOMMENDATION}

In conclusion, methanol extracts displayed the significant highest antioxidant activity among all of the extracts. Besides that, the highest antibacterial activity also observed in methanol extracts. However, there were no significant differences between methanol leaf extracts and methanol rhizome extracts in term of their antioxidant and antibacterial activity. TPC and TFC correlated with reducing power, while TFC correlated with DPPH radicals scavenging activity which suggested that the phenols and flavonoids are the potent bioactive active responsible to the antioxidant activity. The reason that caused the TPC did not show positive correlation to DPPH free radical scavenging activity might be due to the presence of inference in crude extracts as all of the extracts was not subjected to purification. Despite the antioxidant activity was positively regulated by the concentration of phenols and flavonoids concentration, the antibacterial activity was not. Hence, low bioavailability characteristic of alpha-asarone, flavonoid and phenols might be the reason and only active principle of those compounds would show its biological activity. Lower concentration of alpha-asarone was subjected to antioxidant assay also could be possible reason lead to the observation of antibacterial activity did not correlated to TAC. Besides that, beta-asarone was suspected as major compound that contributed to antibacterial activity instead of alphasarone, flavonoids, and phenols.

Using a more advanced extraction method and conducting purification are recommended for further studies in order to maximize the extraction and avoid the miss conclusion on correlation. Overall, both of the hydrophilic (water and methanol) and hydrophobic extracts (hexane extracts) of $A$. calamus could be the potent antioxidant agent for nutraceutical application and antibacterial agent for food application, except for water extracts as no antibacterial activities were examined. However, a sustainable level of antioxidant activities and amount of phenolic and flavonoid compounds were able to be observed in water extracts. Lastly, flavonoids and phenols from sweet flag extracts could be a good potential source of antioxidant for nutraceuticals or food additives.

\section{ACKNOWLEDGEMENT}

Author acknowledges PS Green (KL, Malaysia) for supplying A. calamus for this project, Dr Chan Sook Wah for providing meaningful guidance and loving support throughout the process. Lastly, gratitude was expressed to Taylor's University for providing necessary support and facilities for this project.

\section{CONFLICTS OF INTERESTS}

Authors declare here that do not have any direct financial relation with the plant material suppler mentioned in the paper that might lead to conflict of interests.

\section{REFERENCES}

1. Gupta AD, Bansal BP, Babu, B, Maithil, N. Antioxidant and antimicrobial potential of nutmeg (Myristica fragrans Houtt). Journal of Genetic Engineering and Biotechnology 2011;11(1):25-31.

2. Shukla R, Singh P, Prakash B, Dubey NK. Efficacy of Acorus calamus L.essential oil as a safe plant based antioxidant, aflatoxin B1 suppressor and broad spectrum antimicrobial against food-infesting fungi. International Journal of Food Science and Technology 2013;48:12835 . 
3. Nasri H, Baradaran A, Shirzd H, Rafieian-Kopaei M. New concepts in nutraceuticals as alternative for pharmaceuticals. US National Library of Medicine National Institutes of Health 2014;5(12):1487-99.

4. Institute for Public Health (IPH). National health health and morbidity survey 2014: Malaysian Adult Nutrition Survey Vol II: survey finding. Malaysia: Ministry of Health Malaysia; 2014.

5. Lobo V, Patil A, Phatak A, Chandra N. Free radicals, antioxidants and functional foods: impact on human health. US National Library of Medicine National Institutes of Health 2010;4(8):118-26.

6. Rajput SB, Karuppayil SM, Tonge MB. An overview on traditional uses and pharmacological profile of. (sweet flag) and other Acorus species' phytomedicine. International Journal of Phytotherapy and Phytophamacology 2014;21(3):268-76.

7. Tiwari N, Chaudhary A, Mishra U. Enthnopharmacological aspect of Acorus calamus: a review. Pharmacologyonline 2010;2:435-45.

8. Mahmoudi S, Khali M, Benkhaled A, Benamirouche K, Baiti I. Phenolic and flavonoid contents, antioxidant and antimicrobial activities of leaf extracts from ten Algerian ficus carica L. varieties. Asia Pacific Journal of Tropical Biomedicine 2016;6(3):239-45.

9. Manach C, Scalbert A, Morand C, Remesy C, Jimenez, L. Polyphenols: food sources and bioavailability. Am J Clin Nutr 2004:79(5):727-47.

10. Gropper SS, Smith JL, Groff JL. Advanced nutrition and human metabolism: phytochemicals and herbal supplements in health and disease. Canada: Cengage Learning; 2009.

11. Nandakumar S, Menon S, Shailajan S. A rapid HPLC-ESIMS/MS method for determination of $\beta$-asarone, a potential antiepileptic agent in plasma after oral administration of Acorus calamus extract to rats. US National Library of Medicine 2013;3(3):18-26.

12. Shailajan S, Menon S, Swar G, Singh D, Nair S. Estimation of quantitation of $\beta$-asarone from Acorus calamus rhizome and its formulations using validated RP-HPLC method. Pharmaceuticals Method 2015;6(2):94-4.

13. Liu X, Zhao M, Wang J, Yang B, Jiang Y. Antioxidant activity of methanolic extract of emblica fruit (Phyllantbus emblica L.) from six regions in China. J Food Compt Anal 2008;21(3):219-28.

14. Jia Z, Tang M, Wu J. The determination of flavonoid contents in Mulberry and their scavenging effects on superoxide radicals. Food Chem 1999;64(4):555-99.

15. Devi SA, Ganjewala D. Antioxidant activities of methanolic extracts of sweet flag (Acorus calamus) leaves and rhizomes. Journal of Herbs, Spices \& Medicinal Plants 2011;17(1):111.
16. Oyaizu M. Studies on products of browning reactions: antioxidant activities of products of browning reaction prepared from glucosamine. J Nutrit 1986;44:307-15.

17. Devi SA, Ganjewala, D. Antimicrobial activity of Acorus calamus (L).rhizome and leaf extract. Acta Biological Szegediensis 2009;53(1):45-9.

18. Balakumbahan R, Rajamani K, Kumanan, K. Acorus calamus: an overview. Journal of Medicinal Plants Research 2010;4(25):2740-5.

19. Raja AE, Vijayalakshmi M, Devalarao G. Acorus calamus Linn.: chemistry and biologiy. Research Journal of Pharmacy and Technology 2009;2(2):256-61.

20. Ophardt CE. Polarity of organic compounds, Virtual Chemvbook. [series online] 2013 [cited 2016 September 16]. Available from: URL: http://chemistry.elmhurst.edu/ vchembook/213organicfegp.html

21. Sigma-Aldrich. Alpha-asarone. Figure 1: Alpha-asarone structure [series online] 2016 .. [cited 2016 September 16]. Available from: URL: http://www.sigmaaldrich.com/ catalog/product/aldrich/231282?lang=en\&region=MY

22. Devaki M, Nirupama R, Nirupama M, Yajurvedi HN. A protective effect of rhizome extracts of the herb, vacha (Acorus calamus) against oxidative damage: an in vivo and in vitro study. Food Science and Human Wellness 2016;5:76-84.

23. Soderberg T 2016, Solubility, melting points and boiling points. LibreTexts. [series online] 2016 [cited 2016 October 6]. Available from: URL: http://chem.libretexts. org/Textbook_Maps/Organic_Chemistry_Textbook_Maps/ Map\%3A_Organic_Chemistry_With_a_Biological_ Emphasis_(Soderberg)/Chapter_02\%3A_Introduction_to_ organic_structure_and_bonding_II/2.5\%3A_Solubility, melting_points_and_boiling_points

24. George AV. Alcohols, phenols and ethers. [serial online] 2006 [cited 2014 November 13]. Available from: URL: http://sydney.edu.au/science/chemistry/ george/alcohols. html

25. Khoddami A, Wilkes MA, Roberts TH. Techniques for analysis of plant phenolic compounds. Molecules 2013;18(2):2328-75.

26. Kedare SB, Singh RP. Genesis and development of DPPH method of antioxidant assay. Journal of Food Science and Technology 2011;48(4):412-22.

27. Amic D, Davidovi-Amic D, Besl D, Trinajstic N. Structureradical scavenging relationships of flavonoids. Croat Chem Acta 2002;76(1):55-61.

28. Devi SA, Mali AL, Rahee MA, Belinda EDS. Antioxidant Properties of Alpha Asarone. Asian Journal of Biochemistry 2014;9:107-13.

29. Gabriel AA, Joe A, Vinson, JA, Donnelly PE. Folinciocalteau reagent for polyphenolic assay. Int J Food Sci Nutr Diet 2014;3(8):147-56. 
30. Koolen HHF, da Silva FMA, Gozzo FC, de Souza AQL, de Souza, ADL. 'Antioxidant, antimicrobial activities and characterization of phenolic compounds from buriti (Mauritia flexuosa L. f.) by UPLC-ESI-MS/MS'. Food Research International 2013;51(2):467-73.

31. Joshi N, Prakash O, Pant AK. Essential oil composition and in vitro antibacterial activity of rhizome essential oil and $\beta$-asarone from Acorus calamus L. collected from lower Himalayan Region of Utarakhand. Journal of Essential Oil Bearing Plants 2012;15(1):32-7.

32. Phongpaichit S, Pujenjob N, Rukachaisiriku V, Ongsakul M. Antimicrobial activity of the crude methanol extract of Acorus calamus Linn. J Sci Technol 2005;27(2):517-23.
33. Ravn H, Andary C, Kavacs G, Molgaard, P. Caffeic acid as in vitro inhibitors of plant pathogenic bacteria and fungi. Biochemistry System and Ecology 1989;17:174-84.

34. Singh S, Srivastava R, Choudhary S. Antifungal and HPLC analysis of the crude extracts of Acorus calamus, Tinospora cordifolia and Celestrus paniculatus. Journal of Agricultural Technology 2010;6(1): 149-58.

35. Souza JE, Casanova LM, Costa SS. Bioavailability of phenolic compounds: a major challenge for drug development?'. Revista Fitos, Rio de Janeiro 2005;9(1):172.

36. Hayek SA, Gyawali, R, Ibrahim SA. Antimicrobial natural products'. FORMATEX; 2013. 